state (Blumberg et al., 1969). The small number of patients investigated in the present survey, which included only the relatives living in the patients' homes and the fact that we included cases with transient antigenaemia precludes any consideration of this hypothesis. On the other hand, most carriers were children or young people, which supports the observations of Szmuness and Prince (1971), who stressed the importance of an "age factor." They showed that the risk of becoming a chronic carrier is significantly increased if exposure to the HBAg occurs at an early age.

The detection of chronic carriers of HBAg among household relatives of subjects with persistent antigenaemia would suggest that person-to-person transmission needs a close and long-term contact with the virus reservoir, this being unlikely among contacts of subjects with transient antigenaemia. Dietzman et al. (1973) found no evidence of familial spread of HBAg in relatives of six drug addicts who had acute type B hepatitis. An outbreak of hepatitis B was observed in one family included in our survey, however, indicating that in certain conditions liver diseases associated with transient antigenaemia may be source of nonparenteral spread of virus hepatitis.

Our data suggest that relatives of patients with $\mathrm{HBAg}$ positive liver disease are much more likely .0 be carriers of the antigen than the general population is. Investigation of these contacts is worthwhile since it may disclose cases of otherwise unsuspected acute and chronic liver disease as well as healthy carriers of the antigen, whose identification is important in order to limit the spread of hepatitis virus B.
Requests for reprints should be sent to Dr. M. Bruguera.

\section{References}

Almeida J., et al. (1971). Lancet, 2, 849.

Berris, B., et al. (1973). Annals of Internal Medicine, 79, 690

Blumberg, B. S., Friedlaender, J. S., and Woodside, A. (1969). Proceedings of the National Academy of Sciences of the United States of America, 62, 1108.

Bosch, J., Bruguera M., and Rodés J. (1973). Lancet, 2, 457.

Bruguera M., Rodes J., and Terés J. (1973). Medicina Clinica, 61, 65.

Cossart Y., and Vahrman J. (1970). British Medical fournal, 1, 403.

Dietzman D. E., et al. (1973). New England fournal of Medicine, 289, 1409 Fulford, K. W. M., et al. (1973). Lancet, 1, 1470.

Garibaldi R. A., et al. (1972). Fournal of American Medical Association, 220, 1963.

Giles, J., et al. (1969). New English Fournal of Medicine, 218, 119.

Grob, J. J., and Jemelka H. (1971). Lancet, 1, 206.

Gust, I. D., Kaldor, J., and Nastasi, M. (1971). Lancet, 1, 797.

Heathcote, J., and Sherlock, S. (1973). Lancet, 1, 1468.

Heathcote, J., and Sherlock, S. (1973). Lancet, 1, 1468.

Heathcote, J., Tsianides A., and Sherlock S. (1973). Lancet, 2, 593.

Hersh, T., et al. (1971). New England fournal of Medicine, 285, 1363.

Jeffries, D. J., et al. (1973). British Medical fournal, 2, 455.

Koff R. S., and Isselbacher, K. J. (1968). New England fournal of Medicine, 278, 1371 .

Krugman S., Giles, J. P., and Hammond, J. (1967). Fournal of American Medical Association, 200, 365.

Krugman S., and Giles, J. P. (1970). Fournal of American Medical Association, 212, 1019.

Mazzur S. (1973). Lancet, 1, 749.

Pesendorfer F., Kassnitaky, D., and Wewalka F. (1970). Vox Sanguinis, 19, 200.

Schweitzer J. L. et al. (1973). Gastroenterology, 65, 277.

Szmuness, W., and Prince, A. M. (1971). American fournal of Epidemiology, 94, 585.

Szmuness W., et al. (1973). New England fournal of Medicine, 290, 1162.

Wroblewski, F., and la Due J. S. (1956). Proceedings of the Society of Ex-: perimental Biology and Medicine, 91, 569.

\title{
An Outbreak of Streptococcal Skin Sepsis in a Closed Community
}

\author{
C. I. BACKHOUSE, R. Y. CARTWRIGHT
}

British Medical fournal, 1974, 3, 497-499

\section{Summary}

An outbreak of skin sepsis due to $\beta$-haemolytic streptococcus group A M33, T3/13/B3264 occurred in a closed community. Staphylococcus aureus was also present in many of the lesions, but different strains were recognizable by phage typing. Environmental contamination was found. The outbreak was controlled by isolating infected boys and decontaminating the environment. Various aspects of the epidemiology and the pathogenesis of streptococcal infections are discussed.

\section{Introduction}

The $\beta$-haemolytic streptococcus Lancefields group A, Streptococcus pyogenes, was described by Rosenbach in 1884. The two most common sites of streptococcal infection in man are the upper respiratory tract and the skin. The importance of skin

\footnotetext{
General Practice

C. I. BACKHOUSE, M.B., D.oBst.R.c.o.G., Medical Officer, H.M. Prison Service

Public Health Laboratory, St. Luke's Hospital, Guildford, Surrey GU1 3NT

R. Y. CARTWRIGHT, M.B., M.R.C.PATH., Consultant Microbiologist
}

infections, particularly impetigo, has been more fully recognized during the past decade, and differences in the clinical appearances, epidemiology, and pathogenesis of streptococcal infections of skin and pharynx have been reviewed by Wannamaker (1970).

Rammelkamp et al. (1958) produced some evidence that the drying of oropharyngeal secretions reduced their infectivity and concluded that contaminated dust played only a minor role in the spread of streptococcal infections of the upper respiratory tract. They suggested, however, that in favourable conditions skin infections would occur. In the outbreak described here there were no streptococcal sore throats, and skin infection resulted from abrasions sustained mainly in the gymnasium, where heavy environmental contamination with the epidemic strain could be shown.

Epidemics of acute glomerulonephritis associated with skin infection have occurred in Trinidad (Simon et al., 1965) and at the Red Lake Indian Reservation, Minnesota (Kleinman, 1954; Anthony et al., 1967). Investigators of these epidemics have reported previously unrecognized nephritogenic strains of group A streptococci. The relation between impetigo and acute glomerulonephritis is reviewed by Dillon (1972).

\section{The Outbreak}

The outbreak occurred among boys in a detention centre in the South of England. The centre held an average of 100 boys aged 17-20, who usually remained for eight weeks though a few stayed for longer periods. On arrival they slept in single-bed cubicles in dormitory $\mathrm{A}$. They then progressed through open 
dormitories B, C, D1, and D2, which had 24, 24, 18, and 12 beds respectively.

The boys worked in the centre farm and workshop. Each day physical exercises and recreational activities were held in a gymnasium.

The medical care was provided by one of us (C.B.) at a small surgery in the centre. There was a sick bay with four beds.

During December 1972 an increasing number of boys reported to the surgery with minor septic skin abrasions. The abrasions had all been acquired in the centre and were mainly on the knees, elbows, and hands. The lesions were surrounded by local erythema and an area of tenderness. Most boys also had some lymphangitis and regional lymphadenitis, and a few had general malaise, fever, and headache. There was a prompt response in every case to treatment with a three-day course of intramuscular penicillin (Triplopen one phial daily) and topical chlortetracycline (Aureomycin ointment) for seven days.

In the first three weeks of January 1973 a further 15 boys reported septic skin lesions, and Str. pyogenes and Staphylococcus aureus were isolated from swabs which were taken from the last four boys. As a result of these findings all further lesions were examined bacteriologically and a detailed history taken of how and where the lesion was acquired.

Str. pyogenes was isolated from 22 out of 23 swabs examined and Staph. aureus from 15. Ten of the 23 boys stated that their skin had been abraided during exercise or games in the gymnasium. All of the 23 boys had been in the centre for more than 12 days before showing signs of infection. A retrospective analysis of the other boys who had reported with septic lesions showed similar timings. None of the boys developed any of the known sequelae of streptococcal infection. During the period of the outbreak there was no associated increase of upper respiratory tract streptococcal infections in the centre.

Samples of dust were collected from the gymnasium and shown to be heavily contaminated with both Str. pyogenes and Staph. aureus. Environmental contamination was also found in the dormitories and some of the communal areas (table I).

TABLE I-Environmental Contamination by Streptococcus pyogenes and Staphylococcus aureus in 1973 in a Closed Community

\begin{tabular}{|c|c|c|c|c|c|c|}
\hline \multirow[t]{2}{*}{ Source of Dust } & \multicolumn{3}{|c|}{$\begin{array}{c}\text { Streptococcus pyogenes } \\
\text { Group A }\end{array}$} & \multicolumn{3}{|c|}{ Staphylococcus aureus } \\
\hline & January & March & May & January & March & May \\
\hline 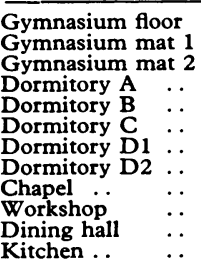 & $\begin{aligned} &+++ \\
&++ \\
&++ \\
&++ \\
&++ \\
&++ \\
&++ \\
&+ \\
&+ \\
&+ \\
& \text { N.I. } \\
& \text { N.I. }\end{aligned}$ & $\begin{array}{l}\text { N.I. } \\
\text { N.I. } \\
\text { N.I. } \\
++^{*} \\
\text { N.I. } \\
+ \\
\text { N.I. } \\
\text { N.I. } \\
\text { N.I. } \\
+^{+*} \\
\text { N.I. } \\
\text { N.I. }\end{array}$ & $\begin{array}{l}\text { N.I. } \\
\text { ”, } \\
\text { ”, } \\
\text { ”, } \\
\text { ”, } \\
\text { ": }\end{array}$ & $\begin{array}{r}+++ \\
++ \\
++ \\
+ \\
++ \\
+ \\
++ \\
+ \\
+ \\
+ \\
+ \\
\text { N.I. } \\
\text { N.I. }\end{array}$ & 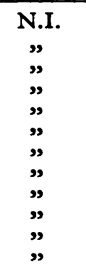 & 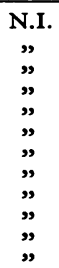 \\
\hline
\end{tabular}

* Strains of Str. pyogenes which were not type M33, T3/13/B3264.

N.I $=$ Not isolated from at least $0.5 \mathrm{~g}$ dust.

Control of the outbreak was achieved by isolating all boys with septic lesions, closing the gymnasium, and thoroughly cleaning the dormitories. No new cases were reported after 15 February, and during the next 12 months only occasional cases of septic skin lesions were reported and no group A streptococci were isolated.

The gymnasium was in a separate building. It had an unsealed wooden strip floor. The gaps between the strips were about 1-4 mm. The floor was cleaned by sweeping. Mats used in the gymnasium had foam rubber backs and many were badly worn. The changing and shower areas had waterproof floors which could be readily cleaned. After closing the gymnasium the wooden floors were sanded and sealed. The mats were all burned.
The dormitory floors were covered with vinyl sheet and were cleaned daily by the boys with brooms and damp tea leaves. Once a week the floors were scrubbed. Each dormitory kept its own cleaning utensils though those from dormitory B were also used to clean the chapel.

During February the dormitories were closed in turn and thoroughly cleaned using a $1 \%$ solution of Stericol. The brooms were all replaced and the use of tea leaves discontinued. Vacuum cleaners were also provided when a dormitory was reopened.

The degree of contamination fell and by May no streptococci or staphylococci were isolated from dust collected in the gymnasium and the dormitories.

\section{Laboratory Findings}

The streptococcal strains isolated were typed at the CrossInfection Laboratory, Colindale. All of them, both from the skin lesions and the dust, were M33, T3/13/B3264.

In March 1973 a new streptococcal type-T12-was isolated from dust collected in dormitory $A$ and the workshop. No associated infection was reported.

Six months before the onset of the outbreak four strains of streptococci isolated from boys in the centre had been typed. Three from skin lesions were T Imp 19 and one from the throat T12.

All the strains of streptococci were sensitive to penicillin, tetracycline, and erythromycin, as determined by disc diffusion.

Ten boys were bled and their streptococcal antibodies estimated at the Cross-Infection Laboratory, Colindale, by antistreptolysin O (A.S.O.) tests (Gooder and Williams, 1959), antideoxyribonuclease B (anti-DNAse B) tests (Nelson et al., 1968), and anti-M-associated protein (anti-M.A.P.) tests (Widdowson et al., 1971). Paired sera were obtained from two boys. The results (table II) are in general agreement with the studies of Kaplan et al. (1970), Dillon and Reeves (1969), and Ferrieri et al. (1972). All the boys had serological evidence of recent streptococcal infection. The greatest increases were seen in the anti-DNAse B antibody titres though many were lower than expected, and in one boy there was no increase.

TABLE II-Streptococcal Antibody Studies

\begin{tabular}{|c|c|c|c|c|}
\hline \multirow{2}{*}{$\begin{array}{l}\text { Case } \\
\text { No. }\end{array}$} & \multirow{2}{*}{$\begin{array}{c}\text { Days after Onset } \\
\text { of Infection }\end{array}$} & \multicolumn{3}{|c|}{ Antibody Titres } \\
\hline & & A.S.O. & Anti-DNAse B & Anti-M.A.P. \\
\hline $\begin{array}{r}1 \\
2 \\
3 \\
4 \\
5 \\
6 \\
7 \\
8 \\
9 \\
10\end{array}$ & $\begin{array}{r}6 \\
12 \\
16 \\
17 \\
17 \\
35 \\
42 \\
42 \\
1 \\
14 \\
7 \\
21\end{array}$ & $\begin{array}{l}320 \\
300 \\
370 \\
220 \\
320 \\
610 \\
330 \\
280 \\
540 \\
470 \\
420 \\
280 \\
\end{array}$ & $\begin{array}{c}600 \\
800 \\
75 \\
800 \\
400 \\
6,400 \\
400 \\
400-600 \\
150 \\
4,800 \\
150 \\
3,200 \\
\end{array}$ & $\begin{array}{l}20-40 \\
40-80 \\
40-80 \\
20 \\
20-40 \\
20-40 \\
40 \\
20-40 \\
40 \\
10-20 \\
40-80 \\
<10 \\
\end{array}$ \\
\hline \multicolumn{2}{|c|}{ Upper limit of normal } & 200 & 250 & 20. \\
\hline
\end{tabular}

Though the A.S.O. titre is generally a poor indicator of streptococcal skin infection the titres of all the sera examined were above the upper limit of normal. In the two sets of paired sera there was a striking difference between the rise in the A.S.O. and anti-DNAse B titres. These differences may, of course, only have reflected the different timing of the antibody response to the two antigens. The anti-M.A.P. titres showed little response (Widdowson et al., 1971). The place of this antibody in the study of streptococcal disease and its sequelae is not yet clearly understood. Type-specific antibodies were not estimated.

Staphylococcal strains were phage typed at Epsom Public Health Laboratory. There were of various phage types in group I and III. All the staphylococci were resistant to penicillin and three also showed resistance to tetracycline. 


\section{Discussion}

Infections with Str. pyogenes are important not only because of the direct pyogenic action but also because of the potentially dangerous sequelae. Rheumatic fever or acute glomerulonephritis may follow upper respiratory tract infection though only nephritis has been described after streptococcal skin infections. The occurrance of nephritis is not related to the severity of the skin lesion, and while it may be associated with widespread impetigo it may also follow minor skin infections. Though only certain types of group A streptococci are nephritogenic all infections with this streptococcal group should be treated seriously.

The potential danger of contaminated dust had been recognized by White (1936), who described pharyngitis developing in a maid who had cleaned a room in which a woman with streptococcal puerperal fever had been nursed. Measures taken to control this environmental reservoir have included the oiling of both the floor and blankets. (Thomas and van den Ende, 1941; White et al., 1944).

In the outbreak we saw, control measures were aimed at the removal of dust and the disinfection of surfaces. The routine cleaning procedures were modified to ensure that the level of dust was kept to a minimum. It was not possible to remove dust adequately from the wood strip floor in the gymnasium until the floor had been sanded and sealed. In residential communities it is advisable that all floors should be sealed and able to withstand regular washing.

Studies in the Red Lake Indian Reservation (Ferrieri et al., 1972; Dajani et al., 1972) suggest that streptococcal infections of both the upper respiratory tract and the skin were preceded by skin colonization. Serial observations on individual children showed that group A streptococci could be recovered from normal skin before the development of skin infections. The mean interval between acquisition and infection was 10 days. $A$ further interval of 14-20 days followed before streptococci could be isolated from the nose or throat. Once skin infection was established there was rapid spread within a family.

During our outbreak the carriage of streptococci on normal skin and in the upper respiratory tract was not assessed. No boy, however, developed a proven streptococcal skin infection during the first 12 days after admission to the centre though all the boys took part in exercises and games during this time. The lack of overt infection during the first 12 days may represent a period of skin carriage.

The principle of containment is important in the control of any communicable disease. It is now the policy in the centre where this outbreak occurred to cover all septic lesions with a waterproof dressing and isolate the boy if necessary. Prompt bacteriological examination is undertaken of all septic lesions. It is hoped that these measures will prevent any further similar outbreaks.

The role of dust as a reservoir of infection in this outbreak illustrates the importance of studying not only the patient but also his environment.

We thank the staff of the Cross-Infection Reference Laboratory, Colindale, for typing the streptococci and measuring the antibody levels; the staff of the Public Health Laboratory, Epsom, for typing the staphylococci; the staff of the detention centre for their cooperation; and all our colleagues for their helpful advice.

\section{References}

Anthony, B. F., et al. (1967). Lancet, 2, 787.

Dajani, A. S., Ferrieri, P., and Wannamaker, L. W. (1972). Fournal of Clinical Investigation, 51, 2863.

Dillon, H. C. (1968). American fournal of Diseases of Children, 115, 530.

Dillon, H. C. (1972). In Streptococci and Streptococcal Diseases, ed. L. W. Wannamaker and J. M. Matsen, p. 571 . Academic Press.

Wannamaker and J. M. Matsen, p. 571 . Academic Press.
Ferrieri, P., et al. (1972). Fournal of Clinical Investigation, 51, 2851.

Ferrieri, P., et al. (1972). Fournal of Clinical Investigation, 51, 2851. Broadsheet No. 25. London, Association of Clinical Pathologists.

Kaplan, E. L., et al. (1970). Fournal of Clinical Investigation, 49, 1405.

Kleinman, H. (1954). Minnesota Medicine, 37, 479.

Nelson, J., Ayoub, E. M., and Wannamaker, L. W. (1968). Fournal of Laboratory and Clinical Medicine, 71, 867.

Rammelkamp, C. H.; et al. (1958). Fournal of Hygiene, Cambridge, 56, 280. Rosenbach, F. J. (1884). Mikroorganismen bei den Wundinfektionskrankheiten. Wiesbaden, Bergmann.

Simon, N. S., Potter, E. V., Seigel, A. C., McAninch, J., Poon-King, T., Humair, L. and Earle, D. P. (1965). Epidemic nephritis in Trinidad, fournal of Laboratory and Clinical Medicine, 66, 1022

Thomas, J. C., and van den Ende, M. (1941). British Medical fournal, 1, 953

Wannamaker, L. W. (1970). New England fournal of Medicine, 282, 23.

Wannamaker, L. W. (1970). Ner

Widdowson, J. P., Maxted, W. R., and Pinney, A. M. (1971). Fournal of Hygiene, Cambridge, 69, 553.

Wright, J., Cruickshank, R., and Gunn, W. (1944). British Medical fournal, 1,611 .

\title{
Relapses after Withdrawal of Proguanil Treatment in Tropical Splenomegaly Syndrome
}

\author{
ABA. S. DAVID-WEST
}

British Medical fournal, 1974, 3, 499-501

\section{Summary}

After the remission of symptoms and reduction in spleen size while on proguanil therapy four patients with the tropical splenomegaly syndrome defaulted from treatment. The withdrawal of proguanil caused a recrudescence of original symptoms, splenomegaly, and a return of the initially raised serum IgM. Complete return to normal values was again effected with proguanil therapy.

\footnotetext{
Department of Haematology, University College Hospital, Ibadan,
Nigeria

ABA S. DAVID-WEST, M.B., PH.D., Senior Registrar
}

The role of the spleen in the tropical splenomegaly syndrome in the production of the raised serum IgM is discussed. These patients should be educated as to the nature of their disease and the importance of continued medical treatment.

\section{Introduction}

The tropical splenomegaly syndrome is associated with anaemia, lymphocytosis in the peripheral blood and bone marrow, hepatic sinusoidal lymphocytosis, and a raised serum IgM. (British Medical fournal, 1967; Pryor, 1967; Richmond et al., 1967; Ziegler et al., 1969; Sagoe, 1970). Tests of immunological competence-phytohaemagglutinin-induced lymphocyte transformation and delayed hypersensitivity skin tests-give normal results. Proguanil and other antimalarials 